\title{
Quality and Acceptability of Restructured Spent Hen Meat Nuggets Prepared from Spent Hen Meat Emulsion and Ground Spent Hen Meat Batter
}

\author{
M. Anna Anandh" and R. Annal Villi \\ Department of Livestock Products Technology, Tamil Nadu Veterinary and Animal Sciences \\ University - Veterinary College and Research Institute, Orathanadu - 614 625, Thanjavur \\ District, Tamil Nadu, India \\ *Corresponding author
}

\begin{tabular}{|l|}
\hline K e y w o r d s \\
Spent, Hen, Meat, \\
Emulsion, Batter, \\
Restructuring, \\
Nuggets, Quality, \\
Acceptability
\end{tabular}

\section{Introduction}

Tremendous growth of poultry industry led to more availability of layers for meat at the end of their productive economic life. Meat from such spent birds is generally tough, dry and sinewy (Mediratta et al., 2004). The disposal of these spent hens is, therefore, becoming more and more difficult due to inherent quality differences between broiler and spent hen meat. Development of further processed products from the spent hen meat would be the most profitable way of utilization of this class of poultry with tough meat. Value enhancement of raw materials, portion control, uniform quality and consumer convenience are some of the advantages of restructured meat products. Products that undergone desinewing and particle size reduction such as sectioning, chunking, slicing, blade tenderization, flaking, chopping followed by forming into steaks, roasts or patties are called 
restructured meats (Hedrick et al., 1994). Restructured meats can be bounded together through the formation of gel that are thermally set (hot-set) (Boles and Shand, 1999).

Restructured meat products are generally prepared by extracting muscle proteins using salt and sodium tri-polyphosphate, which forms a heat set gel upon subsequent cooking. Fine chopped meat contains high levels of extracted myofibrillar proteins that will act as effective binder for water, fat and meat particles in restructured meat products. Meat homogenate or fine chopped meat is prepared by mixing or chopping with salt and phosphate.

Conventional restructured meat products using salt and phosphates depend on the thermal binding of myofibrillar proteins that are extracted from meat (Mandigo, 1986). In this perspective, it is necessary to evolve appropriate technology to convert the tough and less palatable spent hen poultry meat in to convenient, attractive and more acceptable novel products. Hence, a study was undertaken to develop and evaluate the acceptability of spent hen meat nuggets by using spent hen meat emulsion and ground spent hen meat batter.

\section{Materials and Methods}

\section{Spent hen meat}

White leghorn spent hens of about 74 weeks old were purchased from the local poultry farm. The birds were slaughtered following standard procedure, dressed hygienically and manually deboned. The deboned spent hen meat was cut into small chunks and frozen for 1-2 hr to ensure easy mincing. The spent hen meat chunks were minced through the meat mincer (Mado, Germany) using $5 \mathrm{~mm}$ and 20 $\mathrm{mm}$ plates for preparation of emulsion and ground batter, respectively.

\section{Product formulation and treatments}

The basic product formulation consisted of $100 \%$ spent hen meat, $2.7 \%$ salt, $0.5 \%$ sodium tri-polyphosphate, $0.015 \%$ sodium nitrite, $5.0 \%$ vegetable oil, $2.0 \%$ spice mix (aniseed -10 , black pepper - 10, caraway seed -10 , capsicum -8 , cardamom -5 , cinnamon -4 , clove -1 , coriander -20 , cumin seed - 22, turmeric 10 in percentage/weight), $4.0 \%$ refined wheat flour $6.0 \%$ condiments mix (onion and garlic in the ratio of $4: 1$ ) and $10 \%$ ice flakes.

\section{Preparation of spent hen meat emulsion}

Salt, sodium nitrite and sodium tri polyphosphate were added to the minced spent hen meat. The materials were chopped for about 2 min with a Bowl chopper (Scharffen, Germany). After addition of ice flakes it was chopped again for 1-2 min. Refined vegetable oil was added slowly and chopping was continued till the oil was completely dispersed in the batter. Condiments mix, spice mix and refined wheat flour as binder were added and chopping continued for $2 \mathrm{~min}$ to give a fine viscous emulsion.

\section{Preparation ground meat batter}

Spent hen meat chunks were initially blended with salt, sodium tri polyphosphate and sodium nitrite for 1.5 min using a meat mixer. After addition of ice flakes, it was blended again until a tacky exudate was formed. Condiments mix, spice mix, refined wheat flour were added and blending was continued at low speed until the formation of a viscous batter.

\section{Product preparation}

Spent hen meat emulsion / ground spent hen meat batter of $500 \mathrm{gm}$ was placed into rectangular aluminum moulds and were 
packed compactly and covered. The moulds were then clipped and tied and the tripe blocks were cooked in a pressure cooker without pressure for $30 \mathrm{~min}$ to reach the internal temperature of the cooked chicken meat blocks to $80 \pm 2^{\circ} \mathrm{C}$. The internal temperature was recorded using digital probe thermometer. The cooked chicken meat blocks were cooled to room temperature, chilled overnight at $4 \pm 2$ ${ }^{\circ} \mathrm{C}$ and cut into slices of $15 \mathrm{~mm}$ thickness using a meat slicer. The slices were manually cut into nuggets $(4 \times 1.5 \times 1.5 \mathrm{~cm})$. The nuggets were aerobically packed in LDPE bags and were used for analysis of various physico chemical characteristics and sensory parameters.

\section{Analytical procedures}

The $\mathrm{pH}$ was determined by using a digital $\mathrm{pH}$ meter (Century Instruments Ltd., Mumbai, India). Twenty-five grams of the meat emulsion / batter was taken in a LDPE bag and heated in a thermostatically controlled water bath at $80 \pm \mathrm{C}$ for $20 \mathrm{~min}$. The stability was calculated from weight loss during cooking and expressed as percentage of the initial weight (Kondaiah et al., 1985). The weight of each spent hen meat block was recorded before and after cooking, the product yield was calculated (product yield $=$ weight of cooked meat block /weight of raw meat block $\times 100)$ and expressed as percentage. Drip loss was determined by reweighing blotted nuggets after one week of storage at 4 $\pm 2{ }^{\circ} \mathrm{C}$ (drip loss $=$ weight loss $/$ initial weight $\times$ 100). Moisture (Oven drying), protein (Kjeldahal) and fat (Soxhl ether extract) contents of the products were determined as per AOAC (1995).

\section{Sensory evaluation}

The spent hen meat nuggets were shallow panfried in refined vegetable oil until golden brown and served to an experienced panel.
The sensory attributes appearance and colour, flavour, juiciness, tenderness, binding and overall acceptability was evaluated on eight point descriptive scale as suggested by Keeton (1983). The sensory score of 8 was extremely desirable, whereas a score of 1 was extremely undesirable.

\section{Statistical analysis}

The data generated from four trials for each experiment was analyzed following standard procedures (Snedecor and Cochran, 1989) for comparing the means and to determine the effect of treatments $(\mathrm{P}<0.01)$.

\section{Results and Discussion}

\section{Physico-chemical characteristics}

Results of physico-chemical parameters of restructured emulsion and ground spent hen batter nuggets are presented in Table 1. The mean $\mathrm{pH}$ of spent hen nuggets prepared from spent hen meat emulsion was significantly $(\mathrm{P}$ $<0.01$ ) higher compared to the restructured spent hen meat nuggets prepared from ground spent hen meat batter. Higher $\mathrm{pH}$ of spent hen meat nuggets prepared from spent hen meat emulsion was may also be attributed to higher protein denaturation during cooking as compared to restructured spent hen meat prepared from ground spent hen meat batter.

The stability for spent hen ground meat batter was significantly $(\mathrm{P}<0.01)$ lower than that of the spent hen meat emulsion. The lower stability for spent hen meat batter might be attributed to its higher moisture content and absence of added fat (Thomas et al., 2006). The product yield of restructured spent hen meat nuggets prepared from spent hen meat emulsion was significantly higher as compared to restructured spent hen meat nuggets prepared from ground spent hen meat batter. 
Table.1 Effect of spent hen meat emulsion and ground spent hen meat batter on physicochemical parameters of restructured spent hen meat nuggets

\begin{tabular}{l}
$\begin{array}{l}\text { Physico-chemical } \\
\text { parameters* }\end{array}$ \\
\hline pH \\
\hline Emulsion stability (\%) \\
\hline Product yield (\%) \\
\hline Drip loss (\%) \\
\hline Moisture (\%) \\
\hline Protein (\%) \\
\hline Fat $(\%)$ \\
\hline
\end{tabular}

\begin{tabular}{|c|c|}
\hline Spent Hen Meat Emulsion & $\begin{array}{c}\text { Ground Spent Hen Meat } \\
\text { Batter }\end{array}$ \\
\hline $6.45 \pm 0.04^{\mathrm{a}}$ & $6.32 \pm 0.02^{\mathrm{b}}$ \\
\hline $92.18 \pm 0.05^{\mathrm{a}}$ & $89.92 \pm 0.08^{\mathrm{b}}$ \\
\hline $90.37 \pm 0.14^{\mathrm{a}}$ & $88.51 \pm 0.12^{\mathrm{b}}$ \\
\hline $4.12 \pm 0.02^{\mathrm{a}}$ & $3.26 \pm 0.02^{\mathrm{b}}$ \\
\hline $68.55 \pm 0.10^{\mathrm{a}}$ & $69.70 \pm 0.12^{\mathrm{b}}$ \\
\hline $18.95 \pm 0.12$ & $18.78 \pm 0.10$ \\
\hline $11.93 \pm 0.14^{\mathrm{a}}$ & $8.92 \pm 0.10^{\mathrm{b}}$ \\
\hline
\end{tabular}

$*$ Number of observations $=4$.

Means bearing same superscripts (lowercase letters) row-wise do not differ significantly $(\mathrm{P}<0.01)$.

Table.2 Effect of spent hen meat emulsion and ground spent hen meat batter on sensory attributes of restructured spent hen meat nuggets

\begin{tabular}{|l|c|c|}
\hline $\begin{array}{l}\text { Sensory attributes } \\
\text { Appearance and colour }\end{array}$ & $\begin{array}{c}\text { Spent Hen Meat Emulsion } \\
\text { Fround Spent Hen Meat } \\
\text { Batter }\end{array}$ \\
\hline Flavour & $7.5 \pm 0.02^{\mathrm{a}}$ & $6.9 \pm 0.01^{\mathrm{b}}$ \\
\hline Juiciness & $7.0 \pm 0.04^{\mathrm{a}}$ & $6.8 \pm 0.02^{\mathrm{b}}$ \\
\hline Tenderness & $7.0 \pm 0.02^{\mathrm{a}}$ & $6.5 \pm 0.01^{\mathrm{b}}$ \\
\hline Binding & $7.0 \pm 0.01^{\mathrm{a}}$ & $6.8 \pm 0.02^{\mathrm{b}}$ \\
\hline Overall acceptability & $7.2 \pm 0.02^{\mathrm{a}}$ & $6.7 \pm 0.02^{\mathrm{b}}$ \\
\hline
\end{tabular}

$* *$ Number of observations $=20$.

Sensory attributes of restructured spent hen meat nuggets were evaluated on an 8-point descriptive scale (wherein, 1 $=$ extremely undesirable; $8=$ extremely desirable).

Means bearing same superscripts (lowercase letters) row-wise do not differ significantly $(\mathrm{P}<0.01)$.

The lower yield of restructured ground spent hen meat batter nuggets is mainly due to the higher weight losses during processing this is due to the fact that the spent hen meat nuggets have lower levels of fat which strongly affects the water holding capacity of the batter.

The low product yield of restructured spent hen meat nuggets prepared from ground spent hen meat batter might be also due to its higher particle size and low levels of extraction of protein (Anjaneyulu et al., 1989) which results in shrinkage and expulsion of water during heating. Higher product yield of restructured spent hen meat nuggets prepared from spent hen meat emulsion might be due to the effect of fine chopping. Lin and Keeton (1994) reported increased product yield in pre-cooked meat products by use of coarse grinding. Increased protein extractability, which resulted in greater solubilisation of muscle proteins, might have caused the increased product yield (Xargayo and Lagares, 1992). Drip loss value values were significantly $(P<0.01)$ higher for restructured spent hen meat nuggets prepared from spent hen meat emulsion as compared to restructured spent hen meat nuggets prepared from ground spent hen meat batter. Increased drip loss value was primarily due to moisture 
loss. This might be due to more cellular disruption in the smaller meat pieces and consequently increased cytoplasmic fluid loss (Raharjo et al., 1995).

The moisture content was significantly $(\mathrm{P}<$ 0.01) higher for restructured spent hen meat nuggets prepared from emulsion as compared to restructured spent hen meat nuggets prepared from sent hen ground meat batter. The lower moisture content of restructured spent hen meat nuggets prepared from ground spent hen meat batter might be due to higher drip loss as compared to restructured spent hen meat nuggets prepared from emulsion. Protein content of restructured spent hen meat nuggets prepared from spent hen meat emulsion and ground spent hen meat batter did not vary significantly. Restructured spent hen meat nuggets prepared from ground spent hen meat batter had a significantly $(P<0.01)$ lower fat content compared to restructured emulsion nuggets. The relatively higher fat content of restructured emulsion based nuggets was attributed to the incorporation of refined vegetable oil in the formulation (Thomas et al., 2006).

\section{Sensory characteristics}

Results of sensory evaluation of restructured emulsion and ground spent hen meat batter nuggets are presented in Table 2. The sensory attributes scores for appearance and colour, flavour, juiciness, tenderness, binding and overall acceptability were significantly $(\mathrm{P}<$ 0.01) higher for restructured spent hen meat nuggets prepared from spent hen meat emulsion as compared to restructured spent hen meat nuggets prepared from ground spent hen meat batter. The lower sensory scores observed for restructured spent hen meat nuggets prepared from ground spent hen meat batter as compared to restructured spent hen meat prepared from spent hen meat emulsion might be due to poor binding and lower fat content. The restructured spent hen meat nuggets prepared by emulsion were assessed as moderately to highly acceptable, whereas the restructured spent hen meat nuggets prepared by ground spent hen meat batter were rated as moderately acceptable. Therefore, spent hen meat can be successfully used for value addition in the preparation of comminuted meat products by using spent hen meat emulsion as well as ground spent hen meat batter.

Restructured spent hen meat nuggets prepared by using spent hen meat emulsion had better physico-chemical characteristics and were rated moderately to highly acceptable. Restructured spent hen meat nuggets prepared by ground spent hen meat batter were rated moderately acceptable.

\section{References}

Anjaneyulu, A. S. R., Sharma, N. and Kondaiah, N. 1989. Evaluation of salt, polyphosphates and their blend sat different levels on physico-chemical properties of buffalo meat patties. Meat Science, 25: 293-306.

AOAC, Association of Official Analytical Chemists. 1995. Official methods of Analysis (16 ${ }^{\text {th }}$ ed.). Washington, DC. APHA, American Public Health Association (1984). In M. L. Speck (Ed.), Compendium of methods for the microbiological examination of foods (2nd ed.). Washington, DC.

Boles, J.A. and Shand, P.J. 1999. Effects of raw binder system, meat cut and prior freezing on restructured beef. Meat Science, 53:233-239.

Hedrick, H.B., Aberie, E.T., Forrest, J.C., Judge, M.D. and Merkel, R.A. 1994. Principles of meat science. $3^{\text {rd }}$ edn. Kendell / Hunt Publ Co, Lowa.

Keeton, J. C. 1983. Effect of fat and $\mathrm{Nacl} /$ phosphate levels on the chemical 
and sensory properties of pork patties. Journal of Food Science, 48; 878-881.

Kondaiah, N., Anjaneyulu, A. S. R., Rao, V. K., Sharma, N. and Joshi, H. B. 1985. Effect of salt and phosphate on the quality of buffalo and goat meat. Meat Science, 15: 183-192.

Lin, K. W. and Keeton, J. T. 1994. Determination of optimum particle size for low fat precooked ground beef patties. Journal of Muscle Foods, 12: 63-76.

Mandigo, R.W. 1986. Restructuring of muscle foods. Food Technology, 40:85-89.

Mendiratta, S.K., Anjaneyulu, A.S.R., Lakashmanan, V. and Devatkal, S. 2004. Comparitive efficacy of different tenderizing agents for tenderization of spent hen meat. Indian Journal of Poulttry Science, 39:37-42.
Raharjo, S., Dexter, D. R., Worfel, R. C., Sofos, J. N., Solomon, M. B. and Shultz, G. W. 1995. Quality characteristics of restructured beef steaks manufactured by various techniques. Journal of Food Science, 60: 68-71.

Snedecor GW, Cochran WG. 1989. Statistical methods. $8^{\text {th }}$ edn. Oxford and IBH Publ Co, Calcutta.

Thomas, R., Anjaneyulu, A.S.R. and Kondaiah, N. 2006. Quality and shelf life evaluation of emulsion and restructured buffalo meat nuggets at cold storage (4 \pm 1 _C). Meat Science, 72:373-379.

Xargayo, M. and Lagares, J. 1992. Computerized massaging of meat. Fleishwirtschaft, 4: 2.

\section{How to cite this article:}

Anna Anandh, M. and Annal Villi, R. 2018. Quality and Acceptability of Restructured Spent Hen Meat Nuggets Prepared from Spent Hen Meat Emulsion and Ground Spent Hen Meat Batter. Int.J.Curr.Microbiol.App.Sci. 7(02): 220-225. doi: https://doi.org/10.20546/ijcmas.2018.702.028 